\title{
Development of a PCR-based strategy for CYP2D6 genotyping including gene multiplication of worldwide potential use
}

\author{
Pedro Dorado1, Macarena C. Cáceres², Eulalia Pozo-Guisado², Ma-Li Wong³,Julio Licinio3, and Adrián LLerena1-3 \\ ${ }^{1}$ University of Beira Interior, Covilhã, Portugal, ${ }^{2}$ University of Extremadura, Badajoz, Spain, and ${ }^{3}$ University of California, \\ Los Angeles, CA, USA
}

BioTechniques 39:571-574 (October 2005)

doi 10.2144/000112044

\begin{abstract}
There is growing consensus on the potential use of pharmacogenetics in clinical practice, and hopes have been expressed for application to the improvement of global health. However, two major challenges may lead to widening the "biotechnological gap" between the developing and the industrial world; first the unaffordability of some current technologies for poorer countries, and second the necessity of analyzing all described alleles for every clinical case due to the inability to predict the ethnic group of a given patient. Because of its role in the metabolism of a number of drugs, cytochrome P450 2D6 (CYP2D6) is an excellent candidate for use in the optimization of drug therapy. CYP2D6 is a highly polymorphic gene locus with more than 50 variant alleles, and subjects can be classified as poor metabolizers (PM), extensive metabolizers (EM), or ultrarapid metabolizers (UM) of a given CYP2D6 substrate. Several strategies and methods for CYP2D6 genotyping exist. Some, however, are expensive and laborious. The aim of this study was to design a PCR-based genotyping methodology to allow rapid, straightforward, and inexpensive identification of 90\%-95\% of CYP2D6 PM or UM genotypes for routine clinical use, independent of the individual's ethnic group. CYP2D6 is amplified in initial extra long PCRs (XL-PCRs), which subsequently undergo fragment-length polymorphism analysis for the determination of carriers of CYP2D6 allelic variants. The same XL-PCRs are also used for the determination of CYP2D6 multiplication and 2D6*5 allele (abolished activity). The application of this new strategy for the detection of CYP2D6 mutated alleles and multiplications to routine clinical analysis will enable the PM and UM phenotypes to be predicted and identified at a reasonable cost in a large number of individuals at most locations.
\end{abstract}

\section{INTRODUCTION}

Cytochrome P450 2D6 (CYP2D6) is of great importance for the metabolism of clinically used drugs, of which it metabolizes about 20\%-25\% (1), including antipsychotics, antidepressants, antiarrhythmics, $\beta$ blockers, etc. $(2,3)$. Recently we have shown that the number of CYP2D 6 active genes is related to the dose-corrected plasma concentration of the widely used drugs thioridazine (4), risperidone (5), and fluoxetine (6) and to the QTc interval, and thus, potentially to the risk of cardiotoxicity in patients $(4,7)$.

CYP2D6 is a highly polymorphic gene locus with more than 50 variant alleles that lead to a widely ranging enzymatic activity (www.imm.ki.se/CYPalleles/cyp2d6.htm). The polymorphism of the enzyme results in poor metabolizers (PM), efficient metabolizers (EM), or ultrarapid metabolizers (UM) of CYP2D6 substrate drugs. Subjects with multiple gene copies (UMs) will metabolize drugs more rapidly, and therapeutic plasma levels will not be reached at ordinary drug dosages. Individuals lacking functional CYP2D6 genes (PMs), however, will metabolize selective CYP2D6 substrates at a slower rate (8) and may thus be more prone to adverse effects due to elevated drug plasma levels. In PMs, there may also be a reduced effectiveness of drug therapy when pro-drugs requiring activation by CYP2D6 are used.

The variant CYP2D6 alleles can be classified into categories according to whether they cause abolished, decreased, normal, or increased activity. Although more than 50 different allelic variants have been identified, analyses of CYP2D $6 * 3, C Y P 2 D 6^{*} 4$, CYP2D $6 * 4$ duplication, CYP2D $6 * 5$, and CYP2D $6 * 6$ mutant alleles (abolished activity), and gene duplications of CYP2D6*1 and CYP2D ${ }^{*} 2$ (increased activity) have to be performed to allow a $99 \%$ sensitive prediction of PMs or UMs in clinical routine among White European and White American populations (9). The CYP2D6*10 allele is particularly common among Chinese and Japanese populations and is associated with decreased CYP2D6 activity (10). Furthermore, the presence of the CYP2D $6^{*} 17$ allele among African populations also shows decreased CYP2D6 activity (11). Since, with the mapping of the human genome, the concept of race has become untenable, and given the general increase in admixture of people around the world, there is a need for genotyping for the most frequently identified alleles in a given clinical situation, independent of the location of the ethnic group. In particular, the CYP2D6 allele frequency varies between populations and geographical areas (9), so that in admixed populations (e.g., in North, Central, and South America), it would be very useful to have a genotyping method that would allow the phenotype of a given patient or healthy volunteer to be predicted.

The general use of CYP2D6 genotyping may be of help to increase the use of drug therapy and, hence, of global health $(12,13)$. However, most of the several new strategies and methods for CYP2D6 genotyping, such us single-strand conformation polymorphism (SSCP) $(14,15)$, real-time PCR $(16,17)$, microarrays for DNA analysis $(18,19)$, and TaqMan ${ }^{\circledR}$ real-time PCR $(20)$, are expensive or labor-intensive. This situation may widen the "biotechnological gap" between developed and undeveloped countries.

There have been calls for the use of biotechnologies and pharmacogenetics for improved health in developing countries $(12,13)$. One limitation, however, is the unaffordability of some of the current diagnostic methods. PCR is an affordable molecular diagnostic technology and is already in use in low income regions. The development of a strategy for CYP2D6 genotyping covering the most commonly described alleles could therefore promote the use of these technologies in the developing world. The aim of this study was to design a genotyping method based on extra long PCR (XL-PCR) and PCR restriction fragment-length polymorphism (PCRRFLP) methods to allow rapid, straightforward, and inexpensive identification of $90 \%-95 \%$ of CYP2D 6 PM or UM genotypes in a clinical routine, independent of the individual's ethnic group.

\section{MATERIALS AND METHODS}

For CYP2D6 genotyping, 10-mL blood samples were collected in EDTA tubes, and DNA was extracted using the QIAamp ${ }^{\circledR}$ DNA blood kit (Qiagen, Hilden, Germany). 
Table 1. PCR Primer Sequences

\begin{tabular}{|c|c|c|}
\hline Primers & Sequences & References \\
\hline DPKup & 5'-GTTATCCCAGAAGGCTTTGCAGGCTTCA-3' & 21 \\
\hline DPKlow & 5'-GCCGACTGAGCCCTGGGAGGTAGGTA-3' & 21 \\
\hline 2D6dupl-F & 5'-CCTGGGAAGGCCCCATGGAAG-3' & 22 \\
\hline 2D6dupl-R & 5'-CAGTTACGGCAGTGGTCAGCT-3' & 22 \\
\hline 5'2D6dup & 5'-GCCACCATGGTGTCTTTGCTTTCCTGG-3' & 23 \\
\hline 3'2D6dup & 5'-GGTTTCTTGGCCCGCTGTCCCCACTC-3' & 23 \\
\hline $5^{\prime} 2 \mathrm{D} 6{ }^{*} 5$ & 5'-CACCAGGCACCTGTACTCCTC-3' & 24 \\
\hline $3^{\prime} 2 \mathrm{D} 66^{\star} 5$ & 5'-CAGGCATGAGCTAAGGCACCCAGAC-3' & 24 \\
\hline $5^{\prime} 2 \mathrm{D} 6 * 3$ & 5'-GGTCAGTGGTAAGGACAGGCAGGCCC-3' & 25 \\
\hline $3^{\prime} 2 D 6^{*} 3$ & 5'-TCTCGGGGGGGCTGGGCTGGGTCCCAGGTTGGCC-3' & 25 \\
\hline $5^{\prime} 2 \mathrm{D} 6 * 4$ & 5'-TGCGCAACTTGGGCCTGGGCAAGAAGTCGCTGGACCCG-3' & 25 \\
\hline $3^{\prime} 2 \mathrm{D} 6^{*} 4{ }^{*} 6$ & 5'-CTCGGGAGCTCGCCTTGCAGAGACTC-3' & 25 \\
\hline $5^{\prime} 2 D 6^{*} 6$ & 5'-TGCGCAACTTGGGCCTGGGCAAGAAGTCGCTGGACTAG-3' & 25 \\
\hline $5^{\prime} 2 \mathrm{D} 6^{* 10}$ & 5'-CCTGATGCACCGGCGCCAACGCTGGGCTGCACAGTAC-3' & 25 \\
\hline $3^{\prime} 2 \mathrm{D} 6 * 10$ & 5'-CAAACCTGCTTCСССTTCTCAGCC-3' & 25 \\
\hline $5^{\prime} 2 \mathrm{D} 6 * 17$ & 5'-GGCGAGGACACCGCCGACCGCCCGCCTGTGCCCAGTA-3' & 25 \\
\hline $3^{\prime} 2 \mathrm{D} 6^{*} 1 \times \mathrm{N}$ & 5'-CCTGTCTCAAATGCGGCCAGGCGGTGGGGTA-3' & 25 \\
\hline
\end{tabular}

\section{Determination of CYP2D6 Gene Duplication}

To determine whether individuals were carrying duplicated CYP2D6 genes, XL-PCR was used to amplify a fragment spanning the potential crossover sites. The forward primer (2D6dupl-F) is specific for CYP2D6 $3^{\prime}$ flanking sequences, and the reverse primer (2D6dupl-R) is specific for a CYP2D7 sequence (21). In addition, in the same PCR, the entire CYP2D6 gene was amplified by using forward (DPKup) and reverse (DPKlow) primers (22) (see Table 1). Amplification reactions of $25 \mu \mathrm{L}$ were performed on a Mastercycler ${ }^{\circledR}$ 384 (Eppendorf AG, Hamburg, Germany) in 0.2-mL thin-walled tubes by using $0.375 \mu \mathrm{L}$ of an enzyme blend of Taq and Pwo DNA polymerases (Expand ${ }^{\mathrm{TM}}$ Long Template PCR System; Roche Diagnostics $\mathrm{GmbH}$, Mannheim, Germany). Amplification of 50-100 $\mathrm{ng} / \mathrm{\mu L}$ human genomic DNA was done using $2.5 \mu \mathrm{L}$ PCR buffer $3\left(2.75 \mathrm{mM} \mathrm{MgCl}_{2}\right.$; Expand Long Template PCR System), $0.5 \mathrm{mM}$ each dNTP (Deoxynucleoside Triphosphate Set PCR Grade; Roche Diagnostics $\mathrm{GmbH}$ ), and $0.4 \mu \mathrm{M}$ each primer. The cycling conditions were as follows: 2 min denaturation at $94^{\circ} \mathrm{C}$, then 10 cycles of $95^{\circ} \mathrm{C}$ for $20 \mathrm{~s}, 68^{\circ} \mathrm{C}$ for 4 min, then 20 cycles of $95^{\circ} \mathrm{C}$ for $20 \mathrm{~s}, 68^{\circ} \mathrm{C}$ for $4 \mathrm{~min}$ (increasing $5 \mathrm{~s} / \mathrm{cycle}$ ), and then a final extension step of $7 \mathrm{~min}$ at $68^{\circ} \mathrm{C}$. The PCR product was then analyzed directly by $0.8 \%$ agarose gel electrophoresis, and the DNA was visualized with ethidium bromide. This XL-PCR generated CYP2D6 fragments of $5.1 \mathrm{~kb}$, which subsequently served for PCR-RFLP diagnostics, and $3.5 \mathrm{~kb}$ if the multiplication allele was present (Table 2).

\section{Detection of the CYP2D6 ${ }^{*} 5$ Allele}

To determine whether individuals were carrying CYP2D6*5 allele genes, XL-PCR was performed. The $5^{\prime} 2 \mathrm{D} 6^{*} 5$ and $3^{\prime} 2 \mathrm{D} 66^{*} 5$ primers (23) are specific to identify the presence of the CYP2D $6^{*} 5$ allele $(3.5$ $\mathrm{kb})$. In addition, in the same PCR, the entire CYP2D6 gene $(5.1 \mathrm{~kb})$ was amplified as an internal control of the reaction by using forward DPKup and reverse DPKlow primers (22) (Table1). The amplification reactions, cycling conditions, and DNA analysis were the same as used in the determination of CYP2D6 gene duplication.

\section{Detection of the CYP2D $6 * 3,{ }^{*} 4,{ }^{*} 6,{ }^{*} 10$, and} ${ }^{\star} 17$ Alleles

Subsequent nested PCRs were performed to identify of the presence of the CYP $2 D 6{ }^{*} 3,{ }^{*} 4,{ }^{*} 6,{ }^{*} 10$, and $* 17$ alleles. All reamplifications were carried out in $25-\mu \mathrm{L}$ reactions containing $0.5 \mathrm{U}$ EcoTaq polymerase (Ecogen, Barcelona, Spain), $1 \mu \mathrm{L}$ CYP2D6 template (XL-PCR diluted with water 1:10), $2 \mu \mathrm{M}$ each primer (see Table 1), $0.2 \mathrm{mM}$ each dNTP, and $1.2 \mathrm{mM} \mathrm{MgCl}_{2}$. The cycling conditions were: 1 min denaturation at $94^{\circ} \mathrm{C}$, then 30 cycles (except the $2 D 6^{*} 6$ assay, which has 20 cycles) of $94^{\circ} \mathrm{C}$ for $10 \mathrm{~s}, 65^{\circ} \mathrm{C}$ for $20 \mathrm{~s}, 72^{\circ} \mathrm{C}$ for 20 $\mathrm{s}$, and then a final extension step of $7 \mathrm{~min}$ at $72^{\circ} \mathrm{C}$.

Subsequently, $8 \mu \mathrm{L}$ PCR were digested with 5-10 U restriction enzyme (New England Biolabs, Beverly, MA, USA) (see Table 2), followed by an overnight incubation to attain complete digestion. The PCR product was then analyzed directly by $3 \%$ agarose gel electrophoresis. The DNA was visualized with ethidium bromide. Table 2 summarizes all the reamplification reactions performed.

\section{Detection of the CYP2D6 ${ }^{\star} 1,{ }^{\star} 2$, or ${ }^{\star} 4$ Duplication Alleles}

All DNAs possessing gene duplications were further characterized for a CYP2D $6{ }^{*} 1 \times N$, ${ }^{*} 2 \times N$, and ${ }^{*} 4 \times N$ alleles using $1 \mu \mathrm{L}$ XL-PCR template (diluted with water 1:10) producing $10 \mathrm{~kb}$. This XL-PCR was performed using the primers 5'2D6dup and 3'2D6dup (Table 1). Amplification reactions of $25 \mu \mathrm{L}$ were performed in 0.2 $\mathrm{mL}$ thin-walled tubes using $0.375 \mu \mathrm{L}$ of an enzyme blend of Taq and Pwo DNA polymerases. Amplification of 50-100 $\mathrm{ng} / \mu \mathrm{L}$ human genomic DNA was done using $2.5 \mu \mathrm{L}$ PCR buffer $2\left(2.75 \mathrm{mM} \mathrm{MgCl}_{2}\right.$; Expand Long Template PCR System), 0.5 mM each dNTPs (Deoxy-

Table 2. Amplification and Reamplification Reactions Performed for the Determination of CYP2D6 Variant Alleles

\begin{tabular}{|c|c|c|c|c|c|}
\hline \multicolumn{2}{|c|}{ Forward Primers } & \multicolumn{2}{|c|}{ Reverse Primers } & \multicolumn{2}{|c|}{$\begin{array}{l}\text { Results } \\
\text { (bp) }\end{array}$} \\
\hline \multicolumn{2}{|c|}{$\begin{array}{l}\text { DPKup } \\
\text { 2D6dupl-F }\end{array}$} & \multicolumn{2}{|c|}{$\begin{array}{l}\text { DPKlow } \\
\text { 2D6dupl-R }\end{array}$} & \multicolumn{2}{|c|}{$\begin{array}{l}2 D 6 \text { gene: } 5100 \\
* 1,{ }^{*} 2 \text {, or }{ }^{*} 4 \times \mathrm{N}: 3500\end{array}$} \\
\hline \multicolumn{2}{|l|}{$\begin{array}{l}\text { DPKup } \\
5^{\prime} 2 \text { D6*5 }\end{array}$} & \multicolumn{2}{|c|}{$\begin{array}{l}\text { DPKlow } \\
3^{\prime} 2 \mathrm{D} 66^{\star} 5\end{array}$} & \multicolumn{2}{|c|}{$\begin{array}{l}\text { 2D6 gene: } 5100 \\
\text { *5: } 3500\end{array}$} \\
\hline \multicolumn{2}{|l|}{ 5'2D6dup } & \multicolumn{2}{|c|}{ 3'2D6dup } & \multicolumn{2}{|c|}{${ }^{*} 1,{ }^{*} 2,{ }^{*} 4 \times \mathrm{N}: 10,000$} \\
\hline $\begin{array}{l}\text { Forward } \\
\text { Primers }\end{array}$ & $\begin{array}{l}\text { Reverse } \\
\text { Primers }\end{array}$ & $\begin{array}{l}\text { Nucleotide } \\
\text { Identified }\end{array}$ & $\begin{array}{l}\text { PCR } \\
\text { (bp) }\end{array}$ & $\begin{array}{l}\text { Restriction } \\
\text { Enzyme }\end{array}$ & $\begin{array}{l}\text { Results } \\
\text { (bp) }\end{array}$ \\
\hline $5^{\prime} 2 D 6^{*} 3$ & $2^{\prime} \mathrm{D} 6{ }^{*} 3$ & 2637 (A del) & 259 or 258 & Stul & $\begin{array}{c}\text { wt: } 227+32 \\
* 3: 258\end{array}$ \\
\hline $5^{\prime} 2 \mathrm{D} 6 * 10$ & $3^{\prime} 2 \mathrm{D} 6^{*} 10$ & $188(\mathrm{~T})$ & 241 & Scal & $\begin{array}{c}w t: 241 \\
* 4,{ }^{*} 4 \times 2, \text { or } * 10 \\
206+35\end{array}$ \\
\hline $5^{\prime} 2 D 6^{*} 4$ & $3^{\prime} 2 \mathrm{D} 6^{*} 4 /^{*} 6$ & $1934(G)$ & 242 & Pstl & $\begin{array}{c}\text { wt: } 208+34 \\
\quad * 4: 242\end{array}$ \\
\hline $5^{\prime} 2 D 6^{*} 6$ & $3^{\prime} 2 \mathrm{D} 6^{*} 4 /{ }^{*} 6$ & 1795 (T del) & 385 or 384 & Spel & $\begin{array}{c}w t: 351+34 \\
\quad * 6: 384\end{array}$ \\
\hline $5^{\prime} 2 \mathrm{D} 6 * 17$ & 3'2D6dup & $1111(\mathrm{C})$ & 206 & Rsal & $\begin{array}{l}\text { wt: } 170+36 \\
\quad * 17: 206\end{array}$ \\
\hline 5'2D6dup & $3^{\prime} 2 \mathrm{D} 6^{*} 1 \times \mathrm{N}$ & $4268(G)$ & 247 & Banl & $\begin{array}{c}* 2 \times 2: 214+33 \\
* 1 \times 2: 247\end{array}$ \\
\hline wt, wild-ty & & & & & \\
\hline
\end{tabular}




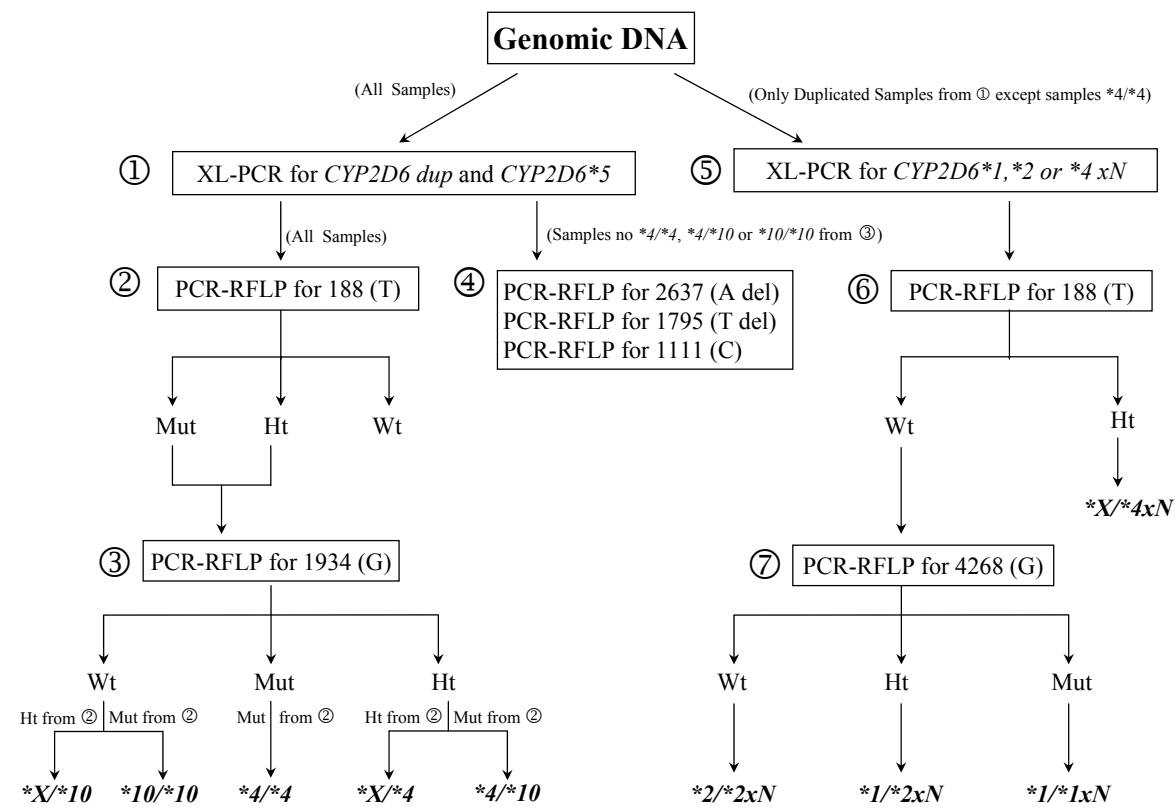

Figure 1. Design of the CYP2D6 genotyping method. The circled numbers represent the order of the steps of the procedure. The PCR restriction fragment-length polymorphism (PCR-RFLP) in step 6 will produce only $\mathrm{Wt}$ or $\mathrm{Ht}$ results because it has not included samples ${ }^{*} 4{ }^{*} 4$ with multiplications. Wt, homozygous with no mutations; Het, heterozygous; Mut, homozygous mutated. ${ }^{*} X$; CYP2D6 variant allele other than ${ }^{*} 4$ or ${ }^{\star} 10$.

While there are several strategies and methods for CYP2D6 genotyping, such us SSCP $(14,15)$, real-time PCR $(16,17)$, microarrays for DNA analysis $(18,19)$, and TaqMan real-time PCR (20), they are expensive and hence unaffordable in many locations. The XL-PCR and PCR-RFLP procedures for CYP2D6 genotyping described in the present study allow the rapid, straightforward, and inexpensive identification of $90 \%-95 \%$ of clinically relevant CYP2D6 genotypes based on an already existing biotechnological method and are suitable for worldwide use.

\section{Conclusions}

CYP2D6 genotyping is a useful tool in clinical medicine. However one of the problems facing its routine use is its cost in terms of labor, equipment, and reagents, especially in admixed populations where a potentially large number of alleles are present. The application of the present PCR-based method to routine clinical analysis will enable PM and UM phenotypes to be

nucleoside Triphosphate Set PCR Grade), and $0.3 \mu \mathrm{M}$ each primer (see Table 1). The cycling conditions were as follows: 2 min denaturation at $94^{\circ} \mathrm{C}$, then 10 cycles of $95^{\circ} \mathrm{C}$ for $20 \mathrm{~s}, 59^{\circ} \mathrm{C}$ for $30 \mathrm{~s}, 68^{\circ} \mathrm{C}$ for $9 \mathrm{~min} 30 \mathrm{~s}$, then 20 cycles of $95^{\circ} \mathrm{C}$ for $20 \mathrm{~s}, 59^{\circ} \mathrm{C}$ for $30 \mathrm{~s}, 68^{\circ} \mathrm{C}$ for $9 \mathrm{~min} 30 \mathrm{~s}$ (increasing $10 \mathrm{~s} / \mathrm{cycle}$ ), and then a final extension of $11 \mathrm{~min}$ at $68^{\circ} \mathrm{C}$. The PCR product was then analyzed directly by $0.8 \%$ agarose gel electrophoresis, and the DNA was visualized with ethidium bromide. This XL-PCR generated a fragment of 10 $\mathrm{kb}$, which subsequently served for PCR-RFLP diagnostics. Then reamplifications were carried out to detect the CYP2D $6^{*} 1 \times N$, ${ }^{*} 2 \times N$, and ${ }^{*} 4 \times N$ alleles. Table 2 summarizes all the reamplification reactions performed.

\section{RESULTS AND DISCUSSION}

The methodological procedure for the detection of CYP2D6 mutated alleles and multiplications are summarized in Figure 1. Genomic DNA is amplified in an initial XL-PCR (Figure 1, step 1) for the determination of CYP2D 6 multiplication and the $2 D 6 * 5$ allele, with each reaction containing two sets of tetraprimers (Table 2). One generated a CYP2D 6 fragment of $5.1 \mathrm{~kb}$, which subsequently served for further PCR-RFLP diagnostics (Figure 1, steps 2-4). The other pair generated $3.5-\mathrm{kb}$ fragments if the $2 D 6^{*} 5$ deletion or the $2 D 6^{*} 1$, ${ }^{*}$, or ${ }^{*} 4$ gene duplication was present. Then, the assays for positions 188 and 1934 were performed to determine carriers of $2 D 6^{*} 4$ and $2 D 6^{*} 10$ alleles (Figure 1, steps 2 and 3). Subsequently, PCR-RFLP analyses were performed to identify the $2 D 6^{*} 3,2 D 6^{*} 6$, and $2 D 6^{*} 17$ variant alleles (Figure 1, step 4).

All DNA possessing a $2 D 6^{*} 1$, *2, and/or *4 multiplicated allele were amplified (except DNAs homozygous for the 2D6*4 allele, because the multiplication is on this allele) producing a $10-\mathrm{kb}$ fragment (Figure 1, step 5), which was amplified for further reamplifications (Figure 1, steps 6 and 7) and to identify which allele carried a duplication. PCR techniques are not capable of differentiating between a gene duplication or multiplication, and for these individuals, a Southern blot analysis needs to be performed to determine the number of CYP2D6 genes present. predicted and identified at a reasonable cost in a large number of individuals covering all ethnic groups. Thus, it might contribute to narrowing the "biotechnological gap" between the industrial and the developing worlds.

\section{ACKNOWLEDGMENTS}

The present study was supported by a grant no. SC.SS.0436 from Junta de Extremadura, Consejería de Sanidad y Consumo, Spain.

\section{COMPETING INTERESTS STATEMENT}

The authors declare no competing interests.

\section{REFERENCES}

1. Ingelman-Sundberg, M. 2004. Pharmacogenetics of cytochrome P450 and its applications in drug therapy: the past, present and future. Trends Pharmacol. 25:193-200.

2. LLerena, A., J. Cobaleda, C. Martinez, and J. Benitez. 1996. Interethnic differences in drug metabolism: influence of genetic and environmental factors on debrisoquine hydroxylation phenotype. Eur. J. Drug Metab. Pharmacokinet. 21:129-138.

3. Dahl, M.L. 2002. Cytochrome p450 phenotyping/genotyping in patients receiving antipsychotics: useful aid to prescribing? Clin. Pharmacokinet. 41:453-470.

4. Berecz, R., A. de la Rubia, P. Dorado, P. Fernandez-Salguero, M.L. Dahl, and A. LLerena. 2003. Thioridazine steady-state plasma concentrations are influenced by tobacco smoking and CYP2D6, but not by the CYP2C9 genotype. Eur. J. Clin. Pharmacol. 59:45-50.

5. Berecz, R., A. LLerena, A. de la Rubia, J. Gomez, M. Kellermann, P. Dorado, and I. Degrell. 2002. Relationship between risperidone and 9-hydroxyrisperidone plasma concentrations and CYP2D6 enzyme activity in psychiatric patients. Pharmacopsychiatry 35:231-234.

6. LLerena, A., P. Dorado, R. Berecz, A.P. Gonzalez, and E.M. Penas-LLedo. 2002. Effect of CYP2D6 and CYP2C9 genotypes on fluoxetine and norfluoxetine plasma concentrations during steady-state conditions. Eur. J. Clin. Pharmacol. 59:869-873.

7. LLerena, A., R. Berecz, P. Dorado, and A. de la Rubia. 2004. QTc interval, CYP2D6 and CYP2C9 genotypes and risperidone plasma concentrations. J. Psychopharmacol. 18:189-193.

8. Dorado, P., R. Berecz, M.C. Caceres, I. Gonzalez, J. Cobaleda, and A. LLerena. 2005. Determination of debrisoquine and 4-hydroxydebrisoquine by high-performance liquid chromatography: application to the evaluation of CYP2D6 genotype and debrisoquine metabolic ratio relationship. Clin. Chem. Lab. Med. 43:275-279. 
9. Bradford, L.D. 2002. CYP2D6 allele frequency in European Caucasians, Asians, Africans and their descendants. Pharmacogenomics 3:229-243.

10. Johansson, I., M. Oscarson, Q.-Y. Yue, L. Bertilsson, F. Sjoqvist, and M. Ingelman-Sundberg. 1994. Genetic analysis of the Chinese cytochrome P4502D locus: characterization of variant CYP2D6 genes present in subjects with diminished capacity for debrisoquine hydroxylation. Mol. Pharmacol. 46:452-459.

11. Oscarson, M., M. Hidestrand, I. Johansson, and M. Ingelman-Sundberg. 1997. A combination of mutations in the CYP2D6*17 (CYP2D6Z) allele causes alterations in enzyme function. Mol. Pharmacol. 52:1034-1040.

12. Daar, A.S., H. Thorsteinsdottir, D.K. Martin, A.C. Smith, S. Nast, and P.A. Singer. 2002. Top ten biotechnologies for improving health in developing countries. Nat. Genet. 32:229-232.

13.Daar, A.S. and P.A. Singer. 2005. Pharmacogenetics and geographical ancestry: implications for drug development and global health. Nat. Rev. Genet. 6:241-246.

14. Broly, F., D. Marez, N. Sabbagh, M. Legrand, S. Millecamps, J.M. Lo Guidice, P. Boone, and U.A. Meyer. 1995. An efficient strategy for detection of known and new mutations of the CYP2D 6 gene using single strand conformation polymorphism analysis. Pharmacogenetics 5:373-384.

15. Marez, D., M. Legrand, M. Sabbagh, J.M. Guidice, C. Spire, J.J. Lafitte, U.A Meyer, and F. Broly. 1997. Polymorphism of the cytochrome P450 CYP2D 6 gene in a European population: characterization of 48 mutations and 53 alleles, their frequencies and evolution. Pharmacogenetics 7:193-202.

16. Hiratsuka, M., Y. Agatsuma, F. Omori, K. Narahara, T. Inoue, Y. Kishikawa, and M. Mizugaki. 2000. High throughput detection of drug-metabolizing enzyme polymorphisms by allele-specific fluorogenic $5^{\prime}$ nuclease chain reaction assay. Biol. Pharm. Bull. 23:1131-1135

17. Molden, E., P.W. Johansen, G.H. Boe, S. Bergan, H. Christensen, H.E. Rugstad, H. Rootwelt, L. Reubsaet, et al. 2002. Pharmacokinetics of diltiazem and its metabolites in relation to CYP2D6 genotype. Clin. Pharmacol. Ther. 72:333-342.

18. Murphy, Jr., G.M., B.G. Pollock, M.A. Kirshner, N. Pascoe, W. Cheuk, B.H. Mulsant, and C.F. Reynolds. 2001. CYP2D6 genotyping with oligonucleotide microarrays and nortriptyline concentrations in geriatric depression. Neuropsychopharmacology 25:737-743.

19. Chou, W.H., F.X. Yan, D.K. Robbins-Weilert, T.B. Ryder, W.W. Liu, C. Perbost, M. Fairchild, J. de Leon, et al. 2003. Comparison of two CYP2D6 genotyping methods and assessment of genotype-phenotype relationships. Clin. Chem. 49:542-551.
20. Schaeffeler, E., M. Schwab, M. Eichelbaum, and U.M. Zanger. 2003. CYP2D6 genotyping strategy based on gene copy number determination by TaqMan realtime PCR. Hum. Mutat. 22:476-485

21. Hersberger, M., J. Marti-Jaun, K. Rentsch, and E. Hanseler. 2000. Rapid detection of the CYP2D $6{ }^{*} 3, C Y P 2 D 6 * 4$, and CYP2D $6 * 6$ alleles by tetra-primer PCR and of the CYP2D $6 * 5$ allele by multiplex long PCR. Clin. Chem. 46:1072-1077.

22.Lundqvist, E., I. Johansson, and M. Ingelman-Sundberg. 1999. Genetic mechanisms for duplication and multiduplication of the human CYP2D6 gene and methods for detection of duplicated CYP2D6 genes. Gene 226:327-338.

23. Johansson, I., E. Lundqvist, M.L. Dahl, and M. Ingelman-Sundberg. 1996 PCR-based genotyping for duplicated and deleted CYP2D6 genes. Pharmacogenetics 6:351-355.

24. Steen, V.M., O.A. Andreassen, A.K. Daly, T. Tefre, A.L. Borresen, J.R. Idle and A.K. Gulbrandsen. 1995. Detection of the poor metabolizer-associated CYP2D6(D) gene deletion allele by long-PCR technology. Pharmacogenetics 5:215-223.

25. Gaedigk, A., R.R. Gotschall, N.S. Forbes, S.D. Simon, G.L. Kearns, and J.S. Leeder. 1999. Optimization of cytochrome P4502D6 (CYP2D6) phenotype assignment using a genotyping algorithm based on allele frequency data. Pharmacogenetics 9:669-682.

Address correspondence to:

Adrián LLerena

Department of Pharmacology and Psychiatry

Faculty of Medicine

University of Extremadura

Avda. de Elvas, s/n

E-06071, Badajoz, Spain

e-mail: allerena@unex.es or allerena@mednet.ucla.edu 